\title{
Proliferative sickle cell retinopathy associated with sickle cell trait and gestational diabetes: case report
}

\author{
Retinopatia falciforme proliferativa associada a traço falciforme \\ e diabetes gestacional: relato de caso
}

\author{
Jefferson Augusto Santana Ribeiro ${ }^{1}$ \\ Daniel da Rocha Lucena ${ }^{2}$ \\ Levy da Rocha Lucena ${ }^{3}$ \\ Rodrig'o Jorg' ${ }^{4}$
}

\begin{tabular}{l} 
ABSTRACT \\
\hline Proliferative sickle cell retinopathy is an uncommon complication in \\
individuals with sickle cell trait (AS). However, the risk for proliferative \\
retinopathy development is increased in patients with AS hemoglobi- \\
nopathy associated with systemic conditions or ocular trauma. A case \\
of a patient with AS hemoglobinopathy who developed proliferative \\
sickle cell retinopathy after the occurrence of gestational diabetes and \\
pregnancy-induced hypertension is reported. Hemoglobin electropho- \\
resis revealed presence of A2 5.0\%, S 35.0\% and A 53.2\%. The present \\
case emphasizes the importance of evaluating systemic comorbidities in \\
patients with sickle cell trait during pregnancy since sickle cell retinopathy \\
can progress rapidly, as well as the importance of regular eye fundus \\
examination in these patients.
\end{tabular}

Keywords: Sickle cell trait; Retinal neovascularization; Retinal detachment; Gestational diabetes; Hypertension, pregnancy-induced; Case reports [Publication type]

\section{INTRODUCTION}

Proliferative sickle cell retinopathy (PSR) is an uncommon complication in individuals with sickle cell trait, also called AS hemoglobinopathy (HAS), occurring more frequently in patients with SC hemoglobinopathy, S-thalassemia and SS hemoglobinopathy ${ }^{(1-2)}$ and after second decade (over 20 years old $)^{(3-4)}$.

However, patients with sickle cell trait associated with systemic conditions or ocular trauma ${ }^{(5)}$ are at increased risk for proliferative retinopathy development, an event not observed in healthy persons with sickle trait ${ }^{(6)}$.

The purpose of the present report is to describe the case of a young patient who developed PSR after pregnancy complicated by diabetes and systemic hypertension.

\section{CASE REPORT}

A 29-year-old black woman with a diagnosis of sickle cell trait, pregnancyinduced hypertension and gestational diabetes developed PSR complications. Visual acuity was evaluated and fluorescein angiogram, ocular echography, hemoglobin electrophoresis and serology were performed.

The patient complained of low visual acuity (VA) in the left eye (OS) for 5 months, with no changes in the right eye (OD). She had a history of systemic arterial hypertension and gestational diabetes during her first 
pregnancy one year ago, when she was treated with regular and NPH insulin and methyldopa until birth. She also had a family history of sickle cell anemia.

At presentation, best corrected VA was 1.0 OD and counting finger in OS. Biomicroscopy of the anterior segment was normal and fundus examination revealed sea fans in OD and vitreous hemorrhage in OS, which prevented retinal examination. Ultrasonography of OS revealed equatorial tractional retinal detachment in superior temporal area and vitreous opacities suggestive of hemorrhage (Figure 1A). She was under no treatment for diabetes or hypertension. Hematocrit value was $37.0 \%$ and hemoglobin level was $12.3 \mathrm{~g} / \mathrm{dL}$. VDRL, FTA-ABS, HIV and toxoplasmosis serology were negative, TST (tuberculin skin test) was $10 \mathrm{~mm}$ and chest radiography showed no alteration. Hemoglobin electrophoresis revealed the presence of A2 5.0\%, S 35\% and A 53.2\%, compatible with sickle cell trait. Fasting blood glucose level was $277 \mathrm{mg} / \mathrm{dL}$ and blood pressure was 120x70 mmHg. PSR was diagnosed; however, the patient did not return for fluorescein angiogram. Eight months after the initial visit, the patient presented for consultation. Best corrected VA was $0.8 \mathrm{OD}$ and counting finger in OS. The patient reported that she had become pregnant and had delivered a premature newborn. Her second pregnancy was also complicated by systemic arterial hypertension and diabetes, and she was treated with regular and NPH insulin and methyldopa until birth. Biomicroscopy of the anterior segment was normal in both eyes and fundus examination revealed fibrovascular proliferation in superior temporal area (equator) associated with tractional retinal detachment and mild vitreous hemorrhage in OD. OS fundoscopy was not possible due to vitreous opacity. Fluorescein angiogram revealed $360^{\circ}$ areas of poor peripheral perfusion and retinal neovessels in superior temporal equator of OD (Figures 1B, C and D). OS ultrasonography was similar to the initial exam, showing presence of
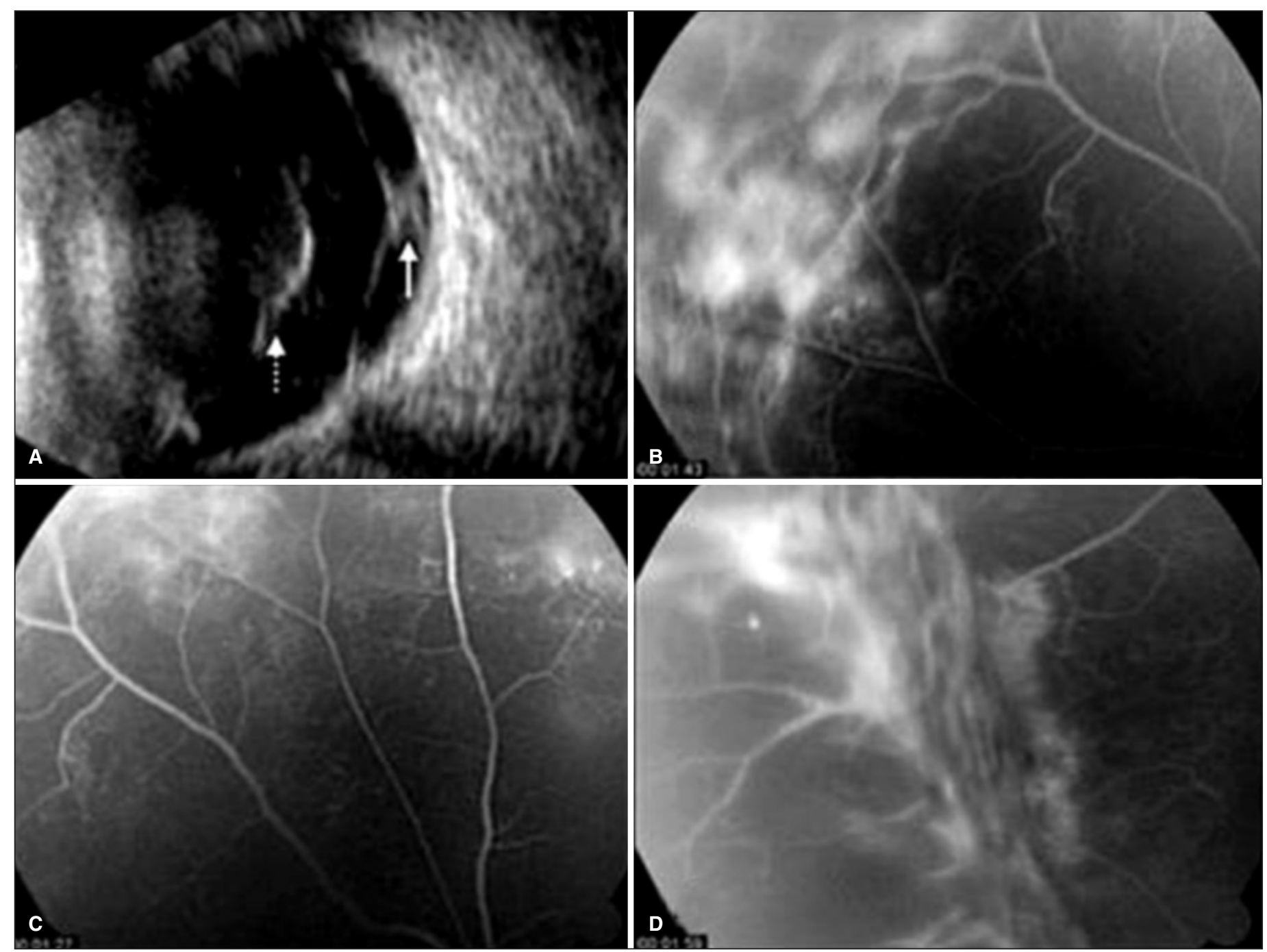

Figure 1 - A) B-mode ultrasonography with a $10 \mathrm{MHz}$ probe in longitudinal section of $12 \mathrm{~h}$ of the left eye showing vitreous hemorrhage (dotted arrow) and traction retinal detachment in superior equatorial area (continuous arrow). B, C, D) Fluorescein angiogram of the right eye showing capillary occlusion and dye leakage in neovessels in equatorial region. Temporal superior (B), superior (C) and temporal inferior (D) areas are shown. 
vitreous hemorrhage and tractional retinal detachment in superior temporal area. Fasting blood glucose level was $143 \mathrm{mg} / \mathrm{dL}$ and blood pressure was $130 \times 85 \mathrm{mmHg}$ with no specific treatment at this time. The patient was treated with $360^{\circ}$ peripheral laser in OD, and an expectant management was adopted for OS. Eleven months after presentation, her VA was 0.9 OD and $0.3 \mathrm{OS}$, and she was under no treatment for diabetes or systemic hypertension. Hemorrhage was completely reabsorbed in OD and partially in OS, which was then submitted to peripheral cryotherapy.

\section{COMMENTARY}

Proliferative sickle cell retinopathy has been described in patients with sickle cell trait associated with systemic arterial hypertension, diabetes mellitus, syphilis, tuberculosis and sar$\operatorname{coidosis}^{(5,7)}$. The patient reported here developed PSR after systemic arterial hypertension and diabetes during her first pregnan$\mathrm{cy}$, and she presented worsening of retinopathy during her second pregnancy, also complicated by hypertension and diabetes.

Peripheral laser photocoagulation, as well as cryotherapy, are effective for PSR treatment, although retinal detachment may occur due to vascular lesions regression and occurrence of retinal tears ${ }^{(8)}$. The patient of the present report was submitted to laser for treatment of OD and cryotherapy for OS due to vitreous hemorrhage, which prevented the use of laser. No adverse events occurred in either eye after treatment.

Factors associated with red cell sickling such as reduced oxygen tension and $\mathrm{pH}$ may occur under certain circumstances in diabetic patients, contributing to sickle cell retinopathy manifestation ${ }^{(7)}$. The patient reported here had diabetes and systemic hypertension during her two pregnancies, which occurred in close sequence within one year, what may have been relevant in triggering PSR.

Thus, we emphasize the importance of evaluating systemic comorbidities in patients with sickle cell trait during pregnancy since rapid progression of sickle cell retinopathy may occur, as well as the importance of regular eye fundus examination in these patients.

\section{RESUMO}

Retinopatia falciforme proliferativa é uma complicação incomum em indivíduos com traço falciforme, havendo, porém, risco aumentado de desenvolver retinopatia proliferativa em pacientes com hemoglobinopatia AS associada a condições sistêmicas ou trauma ocular. Neste artigo será apresentado um caso de paciente com diabetes gestacional, hipertensão arterial sistêmica associada à gravidez e traço falciforme. Eletroforese de hemoglobinas revelou a presença de $\mathrm{A} 25,0 \%, \mathrm{~S} 35,0 \%$ e A $53,2 \%$. Este caso ressalta a importância da avaliação de comorbidades sistêmicas em pacientes com traço falciforme no período gestacional, uma vez que pode ocorrer rápida progressão da retinopatia falciforme, devendo-se realizar também exames regulares do fundo de olho nestes pacientes.

Descritores: Traço falciforme; Neovascularização retiniana; Descolamento de retina; Diabetes gestacional; Hipertensão induzida pela gravidez; Relatos de casos [Tipo de publicação]

\section{REFERENCES}

1. Nagpal KC, Goldberg MF, Rabb MF. Ocular manifestations of sickle hemoglobinopathies. Surv Ophthalmol. 1977;21(5):391-411.

2. Oliveira FVP, Aihara T, Cançado RD. Alteraçöes fundoscópicas nas hemoglobinopatias SS e SC. Arq bras Oftalmol. 1996;59(3):234-8.

3. Gonçalves JCM, Braga JAP, Nione AS, Simoceli RA, Yamamoto M. Retinopatia falciforme em crianças. Arq Bras Oftalmol. 1990;53(4):158-61.

4. Garcia CAA, Fernandes MZ, Uchôa UBC, Cavalcante BM, Uchôa RAC. Achados fundoscópicos em crianças portadoras de anemia falciforme no estado do Rio Grande do Norte. Arq Bras Oftalmol. 2002;65(6):615-8.

5. Jackson H, Bentley CR, Hingorani M, Atkinson P, Aclimandos WA, Thompson GM. Sickle retinopathy in patients with sickle trait. Eye. 1995;9(Pt 5): 589-93

6. Nia J, Lam WC, Kleinman DM, Kirby M, Liu ES, Eng KT. Retinopathy in sickle cell trait: does it exist? Can J Ophthalmol. 2003;38(1):46-51.

7. Nagpal KC, Asdourian GK, Patrianakos D, Goldberg MF, Rabb MF, Goldbaum M, Raichand M. Proliferative retinopathy in sickle cell trait. Report of seven cases. Arch Intern Med. 1977;137(3):325-8.

8. Goldbaum MH, Fletcher RC, Jampol LM, Goldberg MF. Cryotherapy of proliferative sickle retinopathy, II: triple freeze-thaw cycle. Br J Ophthalmol. 1979; 63(2):97-101 